\title{
Telaah Kasus Pencucian Uang Dalam Tinjauan Sistem Ekonomi Syari’ah
}

\section{Sumadi*}

Ikatan Ahli Ekonomi Islam Jawa Tengah, Indonesia

*Email korenpondensi: sumadi@stie-aas.ac.id

Received 07-11-2017| Revised 18-11-2017| Accepted 29-11-2017

\begin{abstract}
Money laundering basically involves assets (income / wealth) that is disguised so that it can be used without being detected that the assets derived from illegal activities. Money laundering through income or assets derived from illegal activity is converted into financial assets that appear to come from legitimate sources. The purpose of this study was to determine how the viewpoint of the Islamic economic system against money laundering, how to solve the problem. This study used a qualitative approach using literature. Results of the study were achieved, in which money laundering is a crime that is so damaging to the country as well, because it can affect or damage the national economy, especially the financial stability of the country. It is completely contrary to the purpose tasyri 'which prevent hazards and create benefits. Money laundering damage, loss, danger, while distancing the benefit of human life, reprehensible, and forbidden that can be called as a crime and in the context of Islamic law. Money loundering view of Islamic law on this money is part immoral acts which leave the required command and does something which is forbidden, where the act was imposed. Thus, the sentence in this case is not determined by the size or the level is, means to determine the lower and upper bounds left entirely to the judge.
\end{abstract}

Keywords : Money laundering, Economic Islam Law, Banking and ill-gotten Money

How to cite: Sumadi, s. (2017). Kasus Pencucian Uang Dalam Tinjauan Sistem Ekonomi Syari'ah. Jurnal Ilmiah Ekonomi Islam, 3(03), 186-192. doi:http://dx.doi.org/10.29040/jiei.v3i03.131

DOI: http://dx.doi.org/10.29040/jiei.v3i03.131

\section{Pendahuluan}

Pencucian uang atau yang sering dikenal dengan istilah money laundering, merupakan metode untuk menyembunyikan, memindahkan, dan menggunakan hasil dari suatu tindakan pidana, kegiatan organisasi kejahatan, kejahatan ekonomi, perdagangan narkotika, dan kegiatankegiatan lainnya yang merupakan aktifitas kejahatan. Money Laundering, pada intinya melibatkan asset (pendapatan/kekayaan) yang disamarkan sehingga dapat dipergunakan tanpa terdeteksi bahwa asset tersebut berasal dari kegiatan illegal. Melaului money laundering pendapatan atau kekayaan yang berasal dari kegiatan yang melawan hukum diubah menjadi asset keuangan yang seolah-olah berasal dari sumber yang sah/legal (sutedi, 2007; Ibarahim, 2004; Husein, 2001).

Istilah pencucian uang atau money laundering telah dikenal sejak tahun 1930 di Amerika Serikat, yaitu ketika Mafia membeli perusahaan yang sah dan resmi sebagai salah satu strateginya. Investasi terbesar adalah perusahaan pencucian pakaian atau disebut Laundromat, yang ketika itu terkenal di Amerika 
Serikat. Usaha pencucian pakaian ini berkembang maju, dan berbagai perolehan uang hasil kejahatan seperti dari cabang usaha lainnya ditanamkan ke perusahaan pencucian pakaian ini. Sebelumnya, pada tahun 1900-an Alphonso Capone atau yang lebih dikenal dengan $\mathrm{Al}$ Capone, penjahat terbesar di Amerika masa lalu, mencuci uang hitam dari usaha kejahatannya dengan memakai si genius Meyer Lansky, orang Polandia. Lansky, seorang akuntan yang mencuci uang kejahatan Al Capone melalui usaha binatu (Laundry). Demikianlah asal muasal muncul nama Money Laundering (Sahetafy, 2011).

Di Indonesia, lembaga perbankan memiliki misi dan fungsi sebagai agen pembangunan (agent of development), yaitu sebagai lembaga yang bertujuan menunjang pelaksanaan pembangunan nasional dalam rangka meningkatkan pemerataan, pertumbuhan ekonomi dan stabilitas nasional kearah peningkatan kesejahteraan rakyat banyak. Kemajuan technologi informasi dan globalisasi keuangan mengakibatkan makin mendunianya perdagangan barang dan jasa serta arus financial. Kemajuan tidak selamnya berdampak positif bagi masyarakat, tetapi terkadang justru menjadi berkembangnya kejahatan terutama kejahatan kerah putih (white collar crime), kejahatan bisnis (business crime), atau kejahatan korporasi (Coorporate crime). Keadaan tersebut dipergunakan oleh orang-orang yang ingin mendapatkan keuntungan dari perbuatan yang tidak halal, yaitu menyelamatkan uang yang diperolehnya, missalnya perdagangan narkotika, hasil korupsi, insider trading dalam jual-beli saham, penyelundupan senjata, pemalsuan kartu kredit dan sebagainya. Di Amerika Serikat misalnya, diperkirakan \$ 100 milyar sampai dengan \$300 milyar dihasilkan dari perdagangan narkotika dan $50 \%$ sampai dengan $70 \%$ dari jumlah tersebut diputihkan dan atau di investasikan kembali.

Penelitian ini sangat penting dilakukan karena untuk mengetahui bagaimana sudut pandang sistem ekonomi Islam terhadap money laundering, bagaimana menyelesaikan permasa- lahan tersebut, yang belum ada pada peneltianpenelitian sebelumnya.

\section{Kajin Pustaka}

Pencucian uang merupakan salah satu kejahatan yang sangat merugikan masyarakat juga negara, karena dapat mempengaruhi atau merusak stabilitas perekonomian nasional khususnya keuangan negara. Hal ini sangat bertentangan dengan tujuan tasyri' yaitu mencegah mafsadah dan menciptakan mashlahah. Pencucian uang menimbulkan kerusakan, kerugian, mudharat, sekaligus menjauhkan kemaslahatan dari kehidupan manusia, tercela, dan terlarang sehingga dapat disebut sebagai tindak pidana dan dalam konteks hukum Islam, dapat dikenai hukuman ta'zir bagi pelakunya (Furqon, 2002)

Institusi Bank memiliki peran dan posisi yang sangat strategis dalam pembangunan nasional, akan tetapi disisi lain bank juga menjadi media arus pencucian uang haram "money laundering" ini. Bank sebagai lembaga perantara keuangan (financial intermediary) menjadi perantara pihak-pihak yang memiliki kelibihan dana (surplus fund), selain itu bank berperan dalam lau lintas pembayaran. Tidak ada masyarakat modern yang dapat mencapai kemajuan pesat tanpa instrument bank. Menurut Compton (1991), tidak mungkin memberi gambaran mengenai ekonomi nasional yang berjalan efisien, tumbuh dengan mantap atau bertahan untuk suatu kurun waktu tanpa dukungan sistem perbankan yang kuat (Compton, 1991).

Begitu besarnya kerugian yang ditimbulkan dari praktik pencucian uang, oleh karena itu upaya untuk mencegah tindak pidana pencucian uang telah dilakukan oleh berbagai Negara. Perang terhadap kegiatan pencucian uang oleh organisasi-organisasi kejahatan dan oleh individu-individu yang tidak tergabung dalam organisasi-organisasi kejahatan telah mencapai tingkat yang jauh lebih serius daripada 15 tahun yang lampau. Badan kerjasama international pertama adalah The Financial Action Task Force 
on Money Laundering (FATF) yang didirikan oleh G7 Summit di Prancis pada bulan Juli 1989.

Undang-Undang tindak pidana pencucian uang dilakukan Indonesia karena desakan internasional. Alasan ini kental sekali karena sejak tiga tahun lalu Indonesia bersama sejumlah negara lain dinilai sebagai negara yang tidak kooperatif dalam menanggulangi pencucian uang dan terancam sanksi internasional terutama oleh Financial Action Task Force karena tidak mempunyai UU tindak pidana pencucian uang.

Pencucian uang merupakan suatu tindak pidana. Sebagaimana diatur dalam suatu Undang-undang yaitu dalam Undang-Undang No. 25 Tahun 2003. Pencucian uang dilakukan tujuan utama pelaku kejahatan melakukan pencucian uang adalah untuk menyamarkan hasil kejahatan agar si pelaku tersebut akhirnya bebas menikmati hasil kejahatannya.

Di Indonesia aturan tentang pencucian uang memang belum lama dibuat peraturan undangundangnya, sejak jatuhnya orde baru (sekitar tahun 1998) banyak kekayaan para pejabat dan terutama kekayaan mantan Presiden Soeharto (keluarga cendana) yang menjadi sorotan publik, disanksikan oleh masyarakat karena diluar kewajaran dan diperkirakan diperoleh dari hasil korupsi selama beliau menjadi Presiden.

Secara umum proses pencucian uang ini dapat dikelompokkan dalam tiga tahap ; Pertama, penempatan (placement), yakni upaya menempatkan uang tunai yang berasal dari tindak pidana ke dalam sistem keuangan, terutama sistem perbankan. Dalam proses ini terdapat pergerakan fisik uang tunai baik melalui penyelundupan uang tunai dari suatu negara ke negara lain, penggabungan antara uang tunai yang berasal dari kejahatan dengan uang yang diperoleh dari hasil kegiatan yang sah.

Kedua, transfer (layering), yakni upaya untuk mentransfer harta kekayaan yang berasal dari tindak pidana (dirty money) yang telah berhasil masuk ke dalam sistem keuangan melalui penempatan (placement). Dalam proses ini terdapat rekayasa untuk memisahkan uang hasil kejahatan dari sumbernya melalui penga- lihan dana hasil placement ke beberapa rekening lainnya dengan serangkaian transaksi yang kompleks. Layering dapat pula dilakukan dengan transaksi jaringan internasional baik melalui bisnis yang sah atau perusahaan yang memiliki nama dan badan hukum namun tidak memiliki kegiatan apapun.

Ketiga, menggunakan harta kekayaan (integration), yakni suatu upaya menggunakan harta kekayaan yang berasal dari tindak pidana yang telah berhasil masuk ke dalam sistem keuangan melalui placement atau layering sehingga seolah-olah menjadi harta kekayaan halal (clean money) untuk kegiatan bisnis yang halal atau untuk membiayai kegiatan kejahatan.

Pencucian uang dapat diselidiki dari transaksi-transaksi nasabah yang mencurigakan. Transaksi keuangan mencurigakan adalah transaksi yang menyimpang dari profil dan karakteristik serta kebiasaan pola transaksi yang dilakukan oleh nasabah, termasuk transaksi keuangan oleh nasabah yang patut diduga dilakukan dengan tujuan untuk menghindari pelaporan transaksi yang bersangkutan yang wajib dilakukan oleh penyedia jasa keuangan.

Beberapa contoh transaksi keuangan yang dapat digunakan untuk mengidentifikasi transaksi keuangan mencurigakan dan kondisi yang sering digunakan dalam pencucian uang, apabila tidak diperoleh informasi yang memuaskan maka transaksi-transaksi dibawah ini harus dipandang sebagai transaksi keuangan mencurigakan (Adyan, 2004); Pertama, nasabah atau kuasanya berupaya menghindari untuk berhubungan langsung dengan penyedia jasa keuangan; Kedua, Penggunaan banyak rekening dengan alasan tidak jelas, Ketiga, penyetoran dalam nominal kecil dengan frekuensi yang cukup tinggi dan kemudian dilakukan penarikan sekaligus; Keempat, Penarikan dalam jumlah besar terhadap rekening tidak aktif; Kelima, Penarikan dalam jumlah besar terhadap rekening yang baru menerima dana yang tidak diduga dan tidak biasa baik dari dalam negeri maupun dari luar negeri; Ke enam, Adanya transfer dana ke dalam suatu rekening dengan frekuensi yang 
sangat tinggi dan secara tiba-tiba padahal sebelumnya rekening tersebut tergolong tidak aktif. (Pencucian Uang : Pengertian, Sejarah, Faktor-faktor Penyebab dan Dampaknya bagi Masyarakat. Jurnal/ Hukum Bisnis).

Nasabah yang berasal dari atau mempunyai rekening di negara yang dikenal sebagai tempat pencucian uang atau negara yang kerahasiaan banknya sangat ketat. Berdasarkan Pasal 13 ayat (1) huruf $b$, Undang-Undang nomor 15 tahun 2002 tentang tindak pidana pencucian uang sebagaimana telah diubah menjadi Undangundang No. 25 tahun 2003, penyedia jasa keuangan (PJK) termasuk didalamnya adalah bank, wajib menyampaikan laporan transaksi yang dilakukan secara tunai dalam jumlah kumulatif sebesar Rp.500.000.000,00 (lima ratus juta rupiah) atau lebih atau mata uang asing yang nilainya setara, baik dilakukan satu kali transaksi maupun beberapa kali transaksi dalam 1 (satu) hari kerja. Laporan transaksi tersebut dikenal sebagai Cash Transaction Report (CTR).

Berdasarkan Pasal 1 angka 8 UndangUndang tindak pidana pencucian uang, yang dimaksud dengan transaksi keuangan yang dilakukan dengan tunai adalah transaksi penarikan, penyetoran, atau penitipan yang dilakukan dengan uang tunai atau instrumen pembayaran lain yang dilakukan melalui Penyedia jasa Keuangan (PJK), sebagai contoh bila nasabah pemegang rekening menyetor tunai minimal sebesar Rp.500.000.000,00 (lima ratus juta rupiah) dalam 1 (satu) hari kerja, maka bank wajib melaporkan transaksi tersebut ke PPATK. Kedua macam laporan tersebut akan digunakan oleh PPATK sebagai data untuk dilakukan analisa dan outputnya menjadi informasi intelejen keuangan yang akan diberikan kepada pihak yang berkompoten antara lain kejaksaan dan kepolisian untuk ditindak lanjuti.

PPATK (Pusat Pelaporan dan Analisis Transaksi Keuangan), sebagai lembaga independen yang bertugas menganalisis semua transaksi keuangan yang mencurigakan yang dilaporkan oleh penyedia jasa keuangan bertanggung jawab langsung kepada Presiden.
PPATK oleh UU TPPU diberi kewenangan untuk membantu penegak hukum memberantas tindak pidana pencucian uang dari berbagai kejahatan, baik oleh perorangan maupun korporasi, dalam batas wilayah negara RI maupun di luar batas wilayah negara RI dengan kerja sama regional dan internasional melalui forum bilateral atau multilateral.

Proses penegakan hukum terhadap laporan data PPATK yang diterima pihak Kepolisian dan Kejaksaan haruslah segera ditindaklanjuti guna mencegah berpindahnya harta kekayaan hasil tindak pidana dan lolosnya pelaku tindak pidana pencucian uang, yang berakibat akan mengurangi efektivitas pencegahan dan pemberantasan tindak pidana pencucian uang. Pencucian uang di Indonesia diselesaikan dengan asas pembuktian terbalik yakni dimana si pelaku menjelaskan sendiri asal harta kekayaan yang dimilikinya di muka pengadilan bahwa harta kekayaanya bukan merupakan hasil dari suatu perbuatan tindak pidana. Dan untuk kelancaran pemeriksaan di pengadilan sekalipun terdakwa dengan alasan yang sah tetapi apabila sampai tiga kali dilakukan pemanggilan untuk sidang tidak hadir, hakim dengan putusan sela dapat meneruskan pemeriksaan dengan tanpa kehadiran terdakwa (secara in absentia), sedangkan apabila diperoleh bukti yang cukup di persidangan bahwa terhadap harta kekayaan terdakwa merupakan hasil tindak pidana, maka dapat disita untuk dikembalikan kepada negara.

Sedangkan kepada terdakwa dipidana dengan pidana penjara paling singkat lima tahun dan paling lama 15 tahun, dan denda paling sedikit Rp 100 juta dan paling banyak Rp 15 miliar. Pemerintah melalui UU No. 15 Tahun 2002 dan diperbaharui menjadi Undang-undang No. 25 Tahun 2003 tentang Tindak Pidana Pencucian Uang berupaya untuk meminimalisir pencucian uang, sampai dengan saat ini pelaksanaan UU tersebut berupaya terus ditingkatkan. Dalam rangka mencegah agar bank tidak dimanfaatkan sebagai sarana pencucian uang, untuk itu Bank Indonesia mengeluarkan peraturan PBI No.3/10/PBI/2001 tentang Prinsip 
Mengenal Nasabah dan diperbaharui dengan PBI No.5/21/PBI/2003 untuk menyesuaikan dengan Undang-undang tahun 2003 tentang perubahan atas Undang-undang No.15 tahun 2002 tentang tindak pidana pencucian uang.

Pembentukan UU tindak pidana pencucian uang ini dimaksudkan agar segala bentuk pencucian uang dapat dicegah dan diberantas serta terhadap pelakunya diberikan sanksi hukum, karena sangat merugikan masyarakat dan Negara yang dapat mempengaruhi serta merusak stabilitas perekonomian nasional atau keuangan negara dan meningkatnya berbagai kejahatan. Hal ini sesungguhnya sangat bertentangan dengan tujuan tasyri' itu sendiri yaitu mencegah mafsadah dan menciptakan maslahah, artinya perbuatan yang justru menimbulkan kerusakan, kerugian, kemudaratan dan sekaligus menjauhkan kemaslahatan kehidupan manusia adalah perbuatan tercela dan terlarang dan perbuatan tersebut dapat disebut sebagai tindak pidana.

\section{Metode Penelitian}

Jenis penelitian ini merupakan penelitian kualitatif dengan menggunakan metode studi pustaka sebagai metodologi penyelesaiannya. Dengan obyek penelitian kasus Money Laundering dilihat dari sudut pandang sistem ekonomi Islam, dan bagaimana ekonomi Islam menyelesaikan permasalahan tersebut (Bungin, 2001).

\section{Hasil dan Pembahasan}

\section{Pandangan ekonomi islam terhadap} money loundering Ekonomi Islam menurut adalah ilmu pengetahuan sosial yang mempelajarai ilmu ekonomi rakyat yang diilhami oleh nilai-nilai Islam. Islam sebagai agama dan ideologi (pandangan hidup), selain mengatur hubungan manusia dengan Allah, Islam juga sangat berkepentingan meletakkan basis-basis etika dan moral dalam hubungan manusia dengan sesama, Islam memiliki konsep yang jelas dalam mengajarkan soal harta, asal harta yang didapatkan dan pendistribusian harta. Islam memiliki ketentuan dalam mendapatkan harta yang benar dan sah, yaitu tidak terdapat unsur al-batil dan az-zalim (QS Al-Baqarah (2) : 188, An-Nisa' (4) : 29 dan 10. Dimana al-batil dan az-zalim yakni jalan yang salah, penindasan, dan eksploitasi, yang sering kali berbentuk penipuan, pencurian, dan perampokan. Oleh karenanya, menjadi sebuah kepastian bahwa Islam melarang pemerolehan harta yang tidak benar dan melanggar ketentuan hukum Islam. Namun seiring berkembangnya waktu, tindak pidana terhadap harta terus berkembang dengan menggunakan istilah-istilah yang baru, termasuk di dalamnya; money laundering, money politic, dll.

Hukum Islam secara detail tidak pernah menyebutkan pelarangan perbuatan pencucian uang, karena memang istilah ini belum ada pada zaman Nabi. Akan tetapi secara umum, ajaran Islam telah mengharamkan mencari rejeki dengan cara-cara yang bathil dan penguasaan yang bukan hak miliknya, seperti perampokan, pencurian, atau pembunuhan yang ada korbannya dan menimbulkan kerugian bagi orang lain atau korban itu sendiri. Namun, berangkat dari kenyataan yang meresahkan, membahayakan, dan merusak, maka hukum pidana Islam perlu membahasnya, bahwa kejahatan ini bisa diklasifikasikan sebagai jarimah ta'zier (Syeikh Zainudin al-Malibari, terjemahan 'irsyadul 'ibad).

Pandangan hukum Islam tentang money laundering ini merupakan bagian jarimah ta'zir. Jarimah ta'zir menurut bahasanya adalah mashdar dari azzara yang berarti menolak atau mencegah kejahatan maupun juga berarti menguatkan, memuliakan, dan membantu. Secara terminologis, jarimah ta 'zir adalah perbuatan maksiat yakni meninggalkan perintah yang diwajibkan dan melakukan perbuatan yang diharamkan, di mana perbuatan itu dikenakan hukuman had maupun kifarat (Nasution, 1965). Maka, tindak pidana pencucian uang masuk dalam kategori jarimah ta'zir dan oleh karenanya dalam Islam, melarang dan mengharamkan kegiatan money laundering.

Di Indonesia money laundering, dilakukan salah satunya melalui institusi perbankan, dimana salah satu institusi perbankan tersebut adalah berlabel Islam, yang disebut dengan 
perbankan syari'ah, sarana tersebut dipergunakan oleh para pelaku money laundering untuk menyelamatkan uang yang diperolehnya Pencucian uang merupakan perbuatan yang sangat merugikan masyarakat, juga negara, karena dapat mempengaruhi atau merusak stabilitas perekonomian nasional khususnya keuangan negara. Hal ini sangat bertentangan dengan tujuan tasyri' yaitu mencegah mafsadah dan menciptakan mashlahah. Pencucian uang menimbulkan kerusakan, kerugian, mudharat, sekaligus menjauhkan kemaslahatan dari kehidupan manusia.

Hukum Ekonomi Islam yang berbasis pada al- Qur'an dan al-Hadits, sebagai suatu sistem kehidupan yang menyeluruh termasuk permasalahan moneter adalah solusi untuk mencegah dari money laundering, sebab dalam prakteknya money laundering merupakan permasalahan moneter yang terjadi di negara-negara Muslim pada khususnya dan negara-negara di dunia pada umumnya.

Berdasarkan pengertian diatas maka apabila suatu tindakan tidak memenuhi unsur obyektif dan subyektif maka tidak dapat dikatakan sebagai tidak pidana (delik). Maka money laudering dapat dikatakan suatu tindakan pidana dan perbuatan tercela, seperti yang diatur dalam Undangundang Republik Indonesia Nomer 15 Tahun 2002 tentang Tindak Pidana Pencucian Uang jo. Undang-undang Nomor 25 Tahun 2003 tentang Perubahan Atas Undang-undang Nomor 15 Tahun 2002. Ini berarti dapat diartikan bahwa kriminalisasi sebagai proses penetapan "pidana".

Berbeda dengan hukum ekonomi konvensional, ekonomi syariah memandang bahwa sebagai sebuah akibatnya apabila suatu tindakan sudah terkodifikasi dalam sebuah hukum atau Undang-undang, maka siapapun yang melanggarnya harus mendapatkan sanksi yang setimpal (hukuman). Mengatakan bahwa diantara nilai transaksi yang terpenting dalam bisnis adalah alamanah 'kejujuran'. Dengan demikian tindakan pencucian uang termasuk tindakan yang tidak jujur. Pencucian uang adalah tindakan yang melanggar hukum, sehingga memerlukan tindak lanjut hukum dari penguasa atau hakim, dalam
al-Qur'an surat al Ma'idah ayat 8 menyatakan bahwa seorang pemimpin harus bertugas menegakkan kebenaran dan keadilan menurut segala apa yang telah ditentukan oleh hukum-hukum syara', maka segala perbuatannya dihubungkan dengan kemaslahatan bagi masyarakat yang di pimpinnya. Dia berhak menjadikan Undangundang untuk melindungi kemslahatan.

Pandangan hukum Islam tentang money laundering ini merupakan bagian jarimah ta'zir. Jarimah ta'zir menurut bahasanya adalah mashdar dari azzara yang berarti menolak atau mencegah kejahatan maupun juga berarti menguatkan, memuliakan, dan membantu. Secara terminologis, jarimah ta'zir adalah perbuatan maksiat yakni meninggalkan perintah yang diwajibkan dan melakukan perbuatan yang diharamkan, di mana perbuatan itu dikenakan hukuman had maupun kifarat. Maka, tindak pidana pencucian uang masuk dalam kategori jarimah ta'zir.

Hukuman dalam jarimah ta'zir tidak ditentukan oleh ukuran atau kadarnya, artinya untuk menentukan batas terendah dan tertinggi diserahkan sepenuhnya kepada hakim. Adapun tujuan ditetapkannya hukum dalam Islam menurut Abdul Qadir Audah, diantaranya; Pertama, Untuk menjaga kemaslahatan masyarakat; Kedua, Untuk memelihara peraturan agar masyarakat tetap eksis; Ketiga, Untuk menjamin kelestarian masyarakat yang kuat dan berakhlak mulia.

Seseorang dapat dikenai sanksi/pidana apabila telah memenuhi unsur jarimah, yaitu; Pertama, Nash yang melarang perbuatan dan mengancamkan hukuman terhadapnya, dan unsur ini biasa disebut "unsur formil" (ar-rukn asysyar'i). Kedua, Adanya tingkah laku yang membentuk jarimah, baik berupa perbuatanperbuatan nyata ataupun sikap tidak berbuat, dan unsur ini biasa disebut "unsur materiil" (ar-rukn al-madi). Ketiga, Pembuat adalah orang mukallaf, yaitu orang yang dapat dimintai pertanggung jawaban terhadap jarimah yang diperbuatnya (Hanafi, 1967) 


\section{Kesimpulan}

Pencucian uang merupakan salah satu kejahatan yang sangat merugikan masyarakat juga negara, karena dapat mempengaruhi atau merusak stabilitas perekonomian nasional khususnya keuangan negara. Hal ini sangat bertentangan dengan tujuan tasyri' yaitu mencegah mafsadah dan menciptakan mashlahah. Pencucian uang menimbulkan kerusakan, kerugian, mudharat, sekaligus menjauhkan kemaslahatan dari kehidupan manusia, tercela, dan terlarang sehingga dapat disebut sebagai tindak pidana dan dalam konteks hukum Islam.

Pandangan hukum Islam tentang money laundering ini merupakan bagian jarimah ta'zir. Jarimah ta'zir menurut bahasanya adalah mashdar dari azzara yang berarti menolak atau mencegah kejahatan maupun juga berarti menguatkan, memuliakan, dan membantu. Secara terminologis, jarimah ta'zir adalah perbuatan maksiat yakni meninggalkan perintah yang diwajibkan dan melakukan perbuatan yang diharamkan, di mana perbuatan itu dikenakan hukuman had maupun kifarat. Maka, tindak pidana pencucian uang masuk dalam kategori jarimah ta'zir. Hukuman dalam jarimah ta'zir tidak ditentukan oleh ukuran atau kadarnya, artinya untuk menentukan batas terendah dan tertinggi diserahkan sepenuhnya kepada hakim.

\section{Ucapan Terima Kasih}

Terimakasih saya sampaikan kepada pihakpihak yang terlibat atas terbitnya tulisan ini, khususnya kepada STIE AAS Surakarta.

\section{Daftar Pustaka}

Compton, N. Eric. (1991). Principle of Banking (terjemahan Alexander Oey. Jakarta: Akademia Pressindo.

Husein, Yunus. (2001). Penerapan Prinsip Mengenal Nasabah oleh Bank dalam Rangka Penanggulangan Kejahatan Money Laundering. artikel pada Jumal Hukum Bisnis. Volume 16 Tahun 2001.

Ibarahim, Yohanes. (2004). Kaidah dan Asas Hukum Perbankan dalam Mengantisipasi Tindak Pidana Pencucian Uang Melalui Transaksi Keuangan Khususnya Perbankan. Artikel pada Jumal Hukum LITIGASI. Fakulats Hukum UNP AS. Bandung. Volume 5 No.2 Juni 2004.

Bungin, B. (2001). Metode Penelitian Kualitatif. Jakarta: PT Rajagrafindo Persada

Adyan, Antory Royan (2004).Politik Kriminal dalam Penanggulangan Terjadinya Tindak Pidana Pencucian Uang di Indonesia. Jurnal Hukum LITIGASI, Fakultas Hukum UNPAS, Bandung, Volume 5 No.2 Juni 2004

Sahetafy, J.E (2011). "Business" Uang Haram komisi hukum nasional. www.khn.go.id

Sutedi, Andrian (2007). Hukum Perbankan: Suatu Tinjauan Pencucian Uang, Merger, Likuidasi, dan kepailitan, Jakarta: Sinar Grafika.

Hanafi, Ahmad (1967). Asas-asas Hukum Pidana Islam. Jakarta: Bulan Bintang

Furqon, arief. (2002). Islam untuk Disiplin Ilmu Hukum. Departemen Agama RI

Nasution, Harun (1965) Islam Ditinjau Dari Berbagai Aspeknya. Jakarta: UI press 